\title{
Molecular Basis of Apolipoprotein (a) Isoform Size Heterogeneity as Revealed by Pulsed-Field Gel Electrophoresis
}

\author{
Carolin Lackner, Eric Boerwinkle, “ Carla C. Leffert, Tracy Rahmig, ${ }^{\star}$ and Helen H. Hobbs \\ Departments of Internal Medicine and Molecular Genetics, University of Texas Southwestern Medical School, Dallas, Texas 75235; \\ * Center for Demographics and Population Genetics, University of Texas Health Science Center, Houston, Texas 77225; and \\ ${ }^{\ddagger}$ GeneScreen, Inc., Dallas, Texas 75235
}

\begin{abstract}
Lipoprotein(a) [Lp(a)] is a cholesterol-rich lipoprotein that is distinguished by its content of a glycoprotein called apolipoprotein(a) [apo(a)]. Apo(a) varies in size among individuals owing to different numbers of cysteine-rich sequences that are homologous to kringle 4 of plasminogen. The genetic basis for this variation is not understood at the genomic level. In this study we used pulsed-field gel electrophoresis and genomic blotting to identify a highly polymorphic restriction fragment from the apo(a) gene. The fragment contains multiple tandem repeats of a kringle 4-encoding sequence and varies in length from 48 to $190 \mathrm{~kb}$ depending on the number of kringle 4-encoding sequences. A total of 19 different alleles were identified among 102 unrelated Caucasian Americans. 94\% of individuals studied had two different alleles which could be distinguished by size on pulsed-field gel electrophoresis. The degree of size heterogeneity was much greater than had been previously appreciated based on the analysis of the apparent molecular mass of the protein.

The size of the apo(a) gene correlated directly with the size of the apo(a) protein, and inversely with the concentration of $\mathbf{L p}(\mathrm{a})$ in plasma. Segregation analysis of the apo(a) gene was performed in families; siblings with identical apo(a) genotypes had similar plasma levels of $L p(a)$. These results suggest that in the normal population, the level of plasma $L p(a)$ is largely determined by alleles at the apo(a) locus. (J. Clin. Invest. 1991. 87:2077-2086.) Key words: contractility • hypertrophy • mitral regurgitation • valvular heart disease
\end{abstract}

\section{Introduction}

A high concentration of lipoprotein(a) $[\mathrm{Lp}(\mathrm{a})]^{1}$ in plasma is an independent risk factor for coronary atherosclerosis (1-4). $\mathrm{Lp}(\mathrm{a})$ has a lipid composition that is nearly identical to low density lipoprotein (LDL), and like LDL, it contains a single copy of apolipoprotein (apo) B-100 (for review, see references 5 and 6). In addition, $\mathrm{Lp}(\mathrm{a})$ contains a large glycoprotein called apo(a), which is attached to apo B by a disulfide bond (7-9).

Address reprint requests to Dr. Hobbs, Department of Molecular Genetics, University of Texas Southwestern Medical Center, 5323 Harry Hines Blvd., Dallas, TX 75235.

Received for publication 19 November 1990 and in revised form 16 January 1991.

1. Abbreviations used in this paper: $\mathrm{Lp}(\mathrm{a})$, lipoprotein(a); PCR, polymerase chain reaction.

J. Clin. Invest.

(C) The American Society for Clinical Investigation, Inc.

0021-9738/91/06/2153/09 \$2.00

Volume 87, June 1991, 2153-2161
The apparent molecular mass of apo(a) can vary from $\sim 280$ to $830 \mathrm{kD}(10-13)$. The differently sized protein isoforms are inherited in a stable, co-dominant Mendelian fashion but are not in Hardy-Weinberg equilibrium (12-14). There are more homozygotes (i.e., individuals with only a single isoform) than would be expected for the observed number of different isoforms in the population. Utermann and his coworkers, as well as others, have shown that the level of plasma $\mathrm{Lp}$ (a) tends to be inversely related to the size of the apo(a) isoforms (12-16). Based on the analysis of the apo(a) protein, it has been estimated that the size variation is responsible for $\sim 41 \%$ of the variability observed in plasma $L p(a)$ levels (16).

The apo(a) protein resembles plasminogen, the plasma zymogen for plasmin (17). The apo(a) and plasminogen cDNAs have been cloned (18-20) and the two genes are closely linked on chromosome 6 (q26-27) (21-25). The two cDNA sequences are remarkably similar (18). The 5 ' untranslated and signal sequence-encoding regions are $98 \%$ and $100 \%$ sequence identical (18). Thereafter, the sequences of the two cDNAs diverge. The signal sequence of the plasminogen cDNA is followed by sequences encoding the "tail" region, five kringles designated $1-5$, and the protease domain. Kringles are 114-amino acid sequences containing six cysteines that form three intra-kringle disulfide bonds. In the apo(a) cDNA, the signal sequence is followed immediately by multiple tandem repeats of a 342basepair sequence that shares $75-85 \%$ homology with the kringle 4-encoding sequence of the plasminogen cDNA. The kringle 4-encoding sequences are followed by a single copy of kringle 5 , and a region that shares $94 \%$ sequence identity with the protease domain of the plasminogen cDNA (18). The plasminogen gene has been cloned (26) but efforts to clone the apo(a) gene have failed. Both apo(a) and plasminogen have multiple pseudogenes and it has been difficult to identify a probe that hybridizes selectively to the apo(a) gene $(27,28)$.

McLean et al. (18) proposed that the size heterogeneity of the apo(a) isoforms is due to different numbers of kringle 4-encoding sequences in the apo(a) gene. In support of this hypothesis, Hixson et al. (29) and Koschinsky et al. (28) found that the size of hepatic apo(a) mRNA in baboons and humans varied and tended to correlate with the size of the apo(a) protein. Attempts have also been made to estimate the number of kringle 4-encoding sequences in the apo(a) gene by examining the relative intensity of bands observed on genomic blots using a kringle 4-specific probe $(30,31)$. In general, the intensity of the kringle 4 fragment correlated with the size of the apo(a) protein $(30,31)$. However, this method gives only a crude estimate of the number of kringle 4-encoding sequences and it can not be used for segregation analysis.

In this paper, we describe a method to directly evaluate the structure of the kringle 4-encoding sequences of the apo(a) gene. We used pulsed-field gel electrophoresis to identify a re- 
striction fragment that contains most, if not all, of the kringle 4-encoding sequences of the apo(a) gene. This fragment is highly polymorphic in the population due to differences in the number of kringle 4-encoding sequences. We have used this polymorphism to explore the relationship between the apo(a) genotype and the level of plasma $\mathrm{Lp}(\mathrm{a})$.

\section{Methods}

Materials. Leukocytes were isolated using LeucoPREP tubes from Becton Dickinson Labware (Lincoln Park, NJ). IA ${ }^{2}$, a polyclonal affinitypurified rabbit anti-human apo(a) antibody, and IgG- $1 \mathrm{~A}^{2}$ (32), a mouse anti-human apo(a) monoclonal antibody (MAb), used in the enzyme-linked immunosorbent sandwich assay (ELISA) were kindly provided by Dr. Gerd Utermann, University of Innsbruck, Austria. IgG-2001, a control mouse MAb directed against an irrelevant antigen, was prepared as described (33). Ponceau-S, used to visualize molecular weight markers on protein gels, was obtained from Sigma Chemical Co., St. Louis, MO. A vertical submarine apparatus with transverse alternating field from GeneLine, Palo Alto, CA was used to perform pulsed-field gel electrophoresis. Low-endosmosis-coefficient agarose, low-melting-point agarose, running buffer (TAFE buffer), and $\lambda$ DNA concatamer used for pulsed-field gel electrophoresis were purchased from Beckman Instruments, Inc., Fullerton, CA. Restriction enzymes were obtained from New England Biolabs, Beverly, MA, and Biotrans nylon membranes used for genomic blotting were obtained from ICN, Irvine, CA. Escherichia coli DNA polymerase I (Klenow fragment) and proteinase $\mathrm{K}$ were obtained from Boehringer Mannheim Biochemicals, Indianapolis, IN. Thermus aquaticus DNA polymerase and the DNA thermal cycler were purchased from Perkin Elmer Cetus, Norwalk, CT. $\left[\alpha{ }^{32} \mathrm{P}\right] \mathrm{dCTP}(3,000 \mathrm{Ci} / \mathrm{mmol})$ was obtained from New England Nuclear, Boston, MA, and ${ }^{125}$ I was obtained from Amersham Corp., Arlington Heights, IL. Iodo-beads used to make radiolabeled antibodies were obtained from Pierce Chemical Co., Rockford, IL. M13 replicative form DNAs were obtained from Pharmacia, Uppsala Sweden. Oligonucleotides used for polymerase chain reaction (PCR)-directed amplification were synthesized on a DNA synthesizer and genomic DNA was purified from leukocytes using a nucleic acid extractor; both machines (models $380 \mathrm{~A}$ and $340 \mathrm{~A}$, respectively) were obtained from Applied Biosystems, Inc., Foster City, CA.

Subjects. Two venous blood samples, at least one of which was fasting, were obtained from 88 unrelated Caucasian American individuals from the Dallas, TX area. A single, fasting blood sample was obtained from 14 additional individuals. Plasma was separated after centrifugation at $2,000 \mathrm{~g}$ for $20 \mathrm{~min}$ at $4^{\circ} \mathrm{C}$. Plasma cholesterol and triglyceride levels were measured by enzymatic assays using kits from Boehringer Mannheim Biochemicals and Sigma Chemical Co. Plasma lipoprotein levels were measured in the laboratory of Dr. Scott Grundy, University of Texas Southwestern Medical Center, Dallas, TX, after ultracentrifugation and heparin-manganese precipitation, according to the procedures of the Lipid Research Clinic (34).

ELISA assay of plasma $L p(a)$. The plasma level of $L p(a)$ was determined at GeneScreen Laboratories, Dallas, TX, using an ELISA exactly as described by Menzel et al. (32). A polyclonal rabbit anti-hu-

A

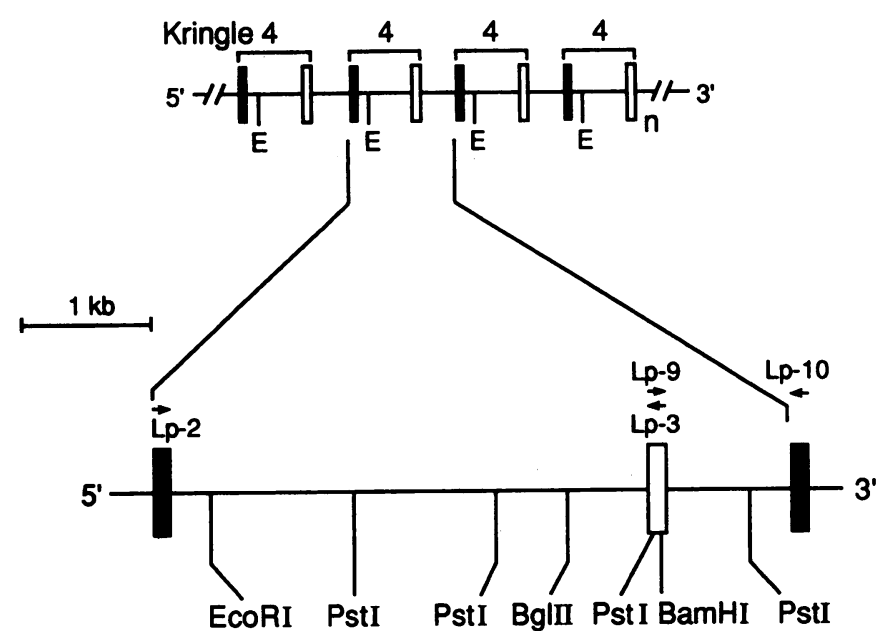

$3^{\prime} \longmapsto 5^{\prime}$ MP-1

B

$$
\begin{aligned}
& \text { MP-1: } 5 \text { - TTCATGATCAAGCCActggaaattccaaaachataca } \\
& \text { PLASMINOGEN: 5' - TTCATTETCAGGCCACtggaaattccaaaacteataca }
\end{aligned}
$$

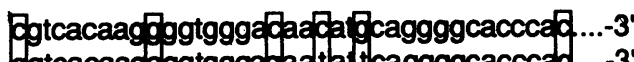

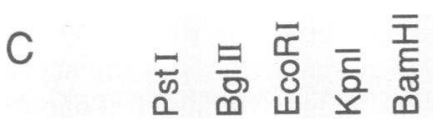

$\mathrm{kb}$

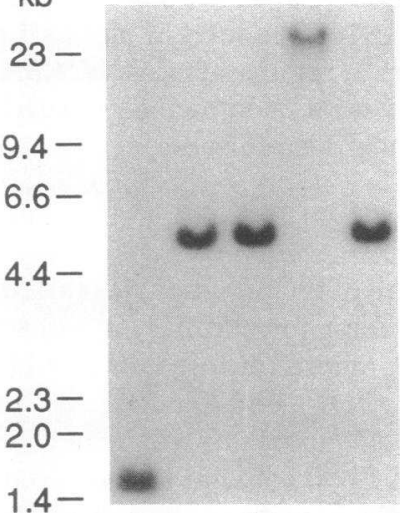

Figure 1. (A) Location of apo(a)-specific probe (MP-1) within the kringle 4-encoding sequence of the apo(a) gene. Each kringle 4-encoding repeat is encoded by two exons, which are demarcated by boxes that are filled in (the first exon) or open (the second exon). The locations of the EcoRI site (demarcated by $E$ ) is given. A single kringle 4-encoding unit has been enlarged. Restriction analysis was performed on DNA selectively amplified by PCR from genomic DNA using Lp-2 (5'-TGACACCACACTCGCATAGTCGGAC-3') and Lp-3 (5'-CTGCGTCTGAGCATTGCGTCAGGTT- $\left.3^{\prime}\right)$ to amplify the large intron between the first and second exon of the kringle 4-encoding repeats, or Lp-9 (5'AAGCCTAGAGGCTCCTTCCGAACAA-3') and LP-10 (5'-CCCCAGGCCTTTGCTCAGTCGGTGC-3') to amplify the region between the repeats. The location of MP-1, the apo(a) kringle 4 specific probe, is given. (B) The sequence of MP-1, which contains 15 base pairs of the apo(a) CDNA sequence, is compared to the published sequence of the corresponding region of the plasminogen gene (26). (C) Southern blotting was performed using $8 \mu \mathrm{g}$ of genomic DNA. The blot was hybridized with $5 \times 10^{6} \mathrm{cpm} / \mathrm{ml}$ of the ${ }^{32} \mathrm{P}$-labeled single-stranded apo(a) kringle 4-specific probe (MP-1), as described in Methods. The filter was washed (38) and exposed to Kodak XAR-5 film and an intensifying screen for $12 \mathrm{~h}$. These sequence data are available from EMBL/GenBank/DDBJ under accession number M64418. 
man apo(a) antibody that had been affinity-purified over an apo(a)coupled Sepharose 4B column was used as the first antibody to coat the solid phase. IgG-1 $\mathrm{A}^{2}$, a mouse anti-human apo(a) MAb, was coupled to horseradish peroxidase and used as a second antibody (35). The Lp(a) plasma standard was obtained from Immuno AG, Vienna, Austria, and had a concentration of $52.4 \mathrm{mg} / \mathrm{dl}$. At least two assays were performed in duplicate on separate plasma samples from each subject and the average of the levels was used for these analyses. The rank correlation coefficient between the two Lp(a) measurements was 0.96 .

Immunoblotting of plasma apo(a). Lp(a) levels were determined by ELISA assay. An aliquot of whole blood (between 0.5 and $10 \mu \mathrm{l}$ ) containing $0.25 \mu \mathrm{g}$ of $\mathrm{Lp}(\mathrm{a})$ was mixed with $30 \mu \mathrm{l}$ of buffer $\mathrm{A}$, which included $15 \% \mathrm{SDS}$ (wt/vol), $8 \mathrm{M}$ urea, $5 \mathrm{mM}$ dithiothreitol, and $62.5 \mathrm{mM}$ Tris at $\mathrm{pH}$ 8.0. The denatured sample was diluted in $60 \mu \mathrm{l}$ of gel loading buffer, which was composed of $10 \%$ glycerol (wt/vol), $0.015 \%$ bromophenol blue (wt/vol), $2.3 \%$ SDS (wt/vol), $5 \% \beta$-mercaptoethanol (vol/ vol), $62.5 \mathrm{mM}$ Tris at $\mathrm{pH} 6.8$, boiled for $10 \mathrm{~min}$, and stored at $-70^{\circ} \mathrm{C}$. The samples were boiled again for 2 min before loading onto a 3-7\% polyacrylamide slab gradient gel with SDS. Electrophoresis was performed for $3 \mathrm{~h}$ at $100 \mathrm{~V}$ and $30 \mathrm{~mA}$, and the proteins were transferred to nitrocellulose as described (33). The filters were incubated in buffer B, which was made up of $500 \mathrm{mM} \mathrm{NaCl}, 5 \%$ powdered skim milk (wt/vol), $0.2 \%$ Tween 20 (vol/vol), and $20 \mathrm{mM}$ Tris at pH 7.4, for 120 min before addition of $1 \%$ Nonidet P-40 (vol/vol) and $0.35 \mu \mathrm{g} / \mathrm{ml}$ of IgG-1 $\mathrm{A}^{2}$. After a 35-min incubation, the filter was washed four times for $10 \mathrm{~min}$ in buffer $\mathrm{C}$, which comprised $500 \mathrm{mM} \mathrm{NaCl}, 20 \mathrm{mM}$ Tris, $1 \%$ Nonidet P-40, $0.5 \%$ deoxycholic acid (wt/vol) $0.1 \%$ SDS at pH 7.4. The blots were then incubated for $45 \mathrm{~min}$ in buffer $\mathrm{C}$ containing 1 $\times 10^{6} \mathrm{cpm} / \mathrm{ml}$ of an ${ }^{125} \mathrm{I}$-radiolabeled rabbit anti-mouse polyclonal antibody $(5,000 \mathrm{cpm} / \mathrm{ng})$. An identical series of washes were performed in buffer $C$, and the blot was again incubated in buffer $B$ for $15 \mathrm{~min}$. The blots were dried and then exposed to XAR-5 film (Eastman Kodak Co., Rochester, NY) and an intensifying screen (Lightening Plus, DuPont Co., Wilmington, DE) at $-70^{\circ} \mathrm{C}$ for the times specified in the figure legends.

Subcloning of apo(a)-specific kringle 4 probe. The PCR was used to amplify the kringle 4-encoding sequence from the apo(a) gene. The kringle 4 repeated unit was amplified using two sets of 25-base oligonucleotides-LP-2 and LP-3 and LP-9 and LP-10 (Fig. $1 A$ ). The template for the oligonucleotides was the kringle 4-encoding sequence which is repeated $>20$ times in the apo(a) cDNA (18). The kringle 4 repeat is encoded by two exons interrupted by a large intervening sequence. The regions between the kringle 4-encoding sequences were amplified by PCR using oligonucleotides which were identical in sequence to the upper strand of the last 25 bases (LP-9) and the lower strand of the first 25 bases of the kringle 4-encoding sequence (LP-10) (Fig. $1 A$ ). Both PCR-directed amplifications were performed using $1 \mu \mathrm{g}$ of genomic DNA as described (36), with the following modifications: the annealing and extension reactions were performed at $68^{\circ} \mathrm{C}$ for $5 \mathrm{~min}$, and the melting temperature was $96^{\circ} \mathrm{C}$ for $1 \mathrm{~min}$.

A single 4.2-kb band was identified when oligonucleotides LP-2 and LP-3 were used in the PCR reaction. The fragment was purified, digested with PstI, and cloned into PstI restricted and dephosphorylated bacteriophage M13-mp18 DNA. The clones containing inserts were sequenced and one, called MP-1, shared 15 bases of sequence identity with the lower strand of the kringle 4-encoding sequence of the apo(a) cDNA (Fig. $1 B$ ). With LP-9 and LP-10, a single 1.3-kb band was identified. Therefore, the total length of a kringle 4 repeat was estimated to be $5.5 \mathrm{~kb}$.

Both the 4.2- and 1.3-kb fragments were digested with a series of restriction enzymes to derive a restriction map for the kringle 4-encoding sequences (Fig. $1 A$ ).

Pulsed-field gel electrophoresis. Mononuclear cells were isolated from $16 \mathrm{ml}$ of blood after centrifugation in LeucoPREP tubes. The cells were washed twice in phosphate-buffered saline (PBS) and suspended to a final cell concentration of $2 \times 10^{7}$ cells $/ \mathrm{ml}$. The cells were diluted in an equal volume of $1 \%(\mathrm{wt} / \mathrm{vol})$ low-melting-temperature agarose. Plugs of cellular agarose were made by injecting $150 \mu \mathrm{l}$ of the cell-agarose mixture into an iced cold plug mold as described (37), with the following modifications: the cellular-agarose plugs were suspended in $10 \mathrm{ml}$ of buffer D ( $1 \% \mathrm{SDS}, 2 \mathrm{mg} / \mathrm{ml}$ proteinase $\mathrm{K}$, and $0.5 \mathrm{M}$ EDTA at $\mathrm{pH} \mathrm{8.0)}$ for $48 \mathrm{~h}$ at $55^{\circ} \mathrm{C}$. The plugs were washed twice in TE $(1 \mathrm{mM}$ EDTA and $10 \mathrm{mM}$ Tris- $\mathrm{HCl}$ at $\mathrm{pH} 8.0$ ) before incubation in TE plus $0.04 \mathrm{mg} / \mathrm{ml}$ phenylmethylsulfonyl fluoride (PMSF) for $30 \mathrm{~min}$ at $55^{\circ} \mathrm{C}$. The plugs were stored in $0.5 \mathrm{M}$ disodium EDTA $(\mathrm{pH} 8.0)$ at $4^{\circ} \mathrm{C}$ for up to $6 \mathrm{mo}$.

A 3-4-mm segment of the plug (containing 1-2 $\mu \mathrm{g}$ of genomic DNA) was washed in TE and digested twice for $2 \mathrm{~h}$ with 40 units of $K p n I$ in a total volume of $170 \mu \mathrm{l}\left(10 \mathrm{mM}\right.$ Tris at pH 7.0, $10 \mathrm{mM} \mathrm{MgCl}_{2}$, $1 \mathrm{mM}$ dithiothreitol, and $1 \mathrm{mg} / \mathrm{ml}$ bovine serum albumin) at $37^{\circ} \mathrm{C}$. After digestion, the plugs were rinsed with TE and then loaded onto a $1 \%$ low endosmosis agarose gel $(7.6 \times 10 \times 0.64 \mathrm{~cm})$ made with 1 $\times$ TAFE buffer $(20 \times$ TAFE buffer contains a $10 \mathrm{mM}$ EDTA [free acid], $87 \mathrm{mM}$ acetic acid, $0.2 \mathrm{M}$ Tris at $\mathrm{pH} 8.0$ ). The wells were sealed

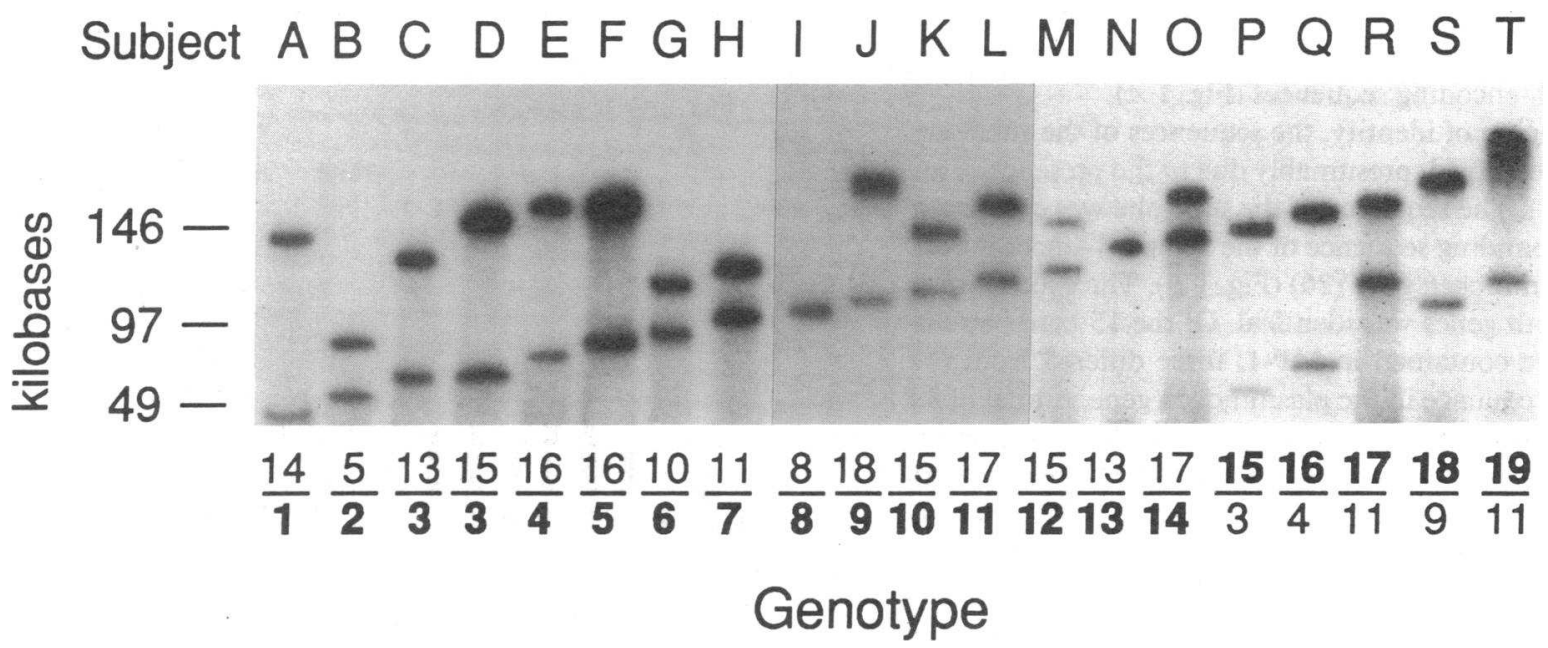

Figure 2. Genomic blot of apo(a) gene after pulsed-field gel electrophoresis. High molecular weight genomic DNA (1-2 $\mu \mathrm{g})$ was digested with $K p n I$, size-fractionated by pulsed-field gel electrophoresis, transferred to a nylon membrane, and hybridized with MP-1, a ${ }^{32} \mathrm{P}-$ labeled singlestranded probe $\left(5 \times 10^{6} \mathrm{cpm} / \mathrm{ml}\right)$, as described in Methods. Preformed concatamers of $\lambda$ phage DNA were used as a size standard. The filter was exposed to Kodak XAR-5 film for $16 \mathrm{~h}$ with an intensifying screen. Lanes A-T show the $19 \mathrm{KpnI}$ restriction fragments of different size identified in the sample of 102 unrelated Caucasian Americans. 
with $1 \%$ (wt/vol) low-melting-temperature agarose. Premade plugs containing lambda phage concatamers (Beckman Instruments, Inc.) were washed in a similar fashion and used as a size standard. The gel was loaded into a precooled $\left(14^{\circ} \mathrm{C}\right)$ GeneLine electrophoresis apparatus. Alternating 4-s pulses at $170 \mathrm{~mA}$ were applied to the gel for $30 \mathrm{~min}$ before 6-s pulses at $150 \mathrm{~mA}(10 \mathrm{~V} / \mathrm{cm})$ for $18 \mathrm{~h}$ at $14^{\circ} \mathrm{C}$. The restricted genomic DNA was transferred to a nylon membrane, baked, and then incubated in prehybridization buffer for $30 \mathrm{~min}$, as described (38). A total of $5 \times 10^{6} \mathrm{cpm} / \mathrm{ml}$ of single-stranded MP-1, radiolabeled according to Church and Gilbert (39), was allowed to incubate with the filter overnight at $42^{\circ} \mathrm{C}$. The filter was washed exactly as described (38) and exposed to X-ray film for $18 \mathrm{~h}$.

Statistical methods. Allele frequencies were estimated by gene counting. Because of the large number of apo(a) restriction fragment length alleles (19 observed in this sample of 102 individuals) most potential genotypes were not observed, and the standard $\chi^{2}$ test for goodness of fit to Hardy-Weinberg equilibrium (40) was inappropriate. Instead, the expected number of homozygotes and heterozygotes was computed and compared to the observed numbers using a standard $\chi^{2}$ statistic with 1 degree of freedom. Using simulated data, this method has been shown to yield results similar to the more complex empirical likelihood ratio test procedure ( $R$. Chakraborty, personal communication). All routine statistical procedures were carried out using BMDP PC-90 statistical programs (41). Because the plasma $\mathrm{Lp}(\mathrm{a})$ levels do not have a normal distribution in the population (12), nonparametric statistical procedures based on the ranks were used throughout (42).

\section{Results}

To determine the molecular basis for the size heterogeneity found in the apo(a) protein, the structure of the apo(a) gene was explored by genomic blotting using pulsed-field gel electrophoresis. An apo(a) gene-specific probe was generated by PCR-directed amplification of kringle 4-encoding sequences in the apo(a) gene. Two oppositely oriented 25-base oligonucleotides, Lp-2 and Lp-3, which were identical in sequence to the most common kringle 4-encoding sequence in the apo(a) cDNA (18) were used to amplify the intervening sequences by PCR. The expected size of the amplification product (assuming no intervening sequences) was 162 base pairs, but the observed size of the fragment was $4.2 \mathrm{~kb}$. The amplified fragment was restricted with PstI, and subcloned into the bacteriophage M13-mp18. One of the subclones, MP-1, contained a 1.5-kb insert which shared 15 base pairs of sequence identity with the apo(a) kringle 4-encoding sequences (Fig. $1 A$ ).

After this region of identity, the sequences of the subclone and the cDNA diverged, presumably due to the presence of an intron (Fig. $1 A$ ). The sequence of the subclone was compared with the corresponding sequence of the kringle 4-encoding region of the plasminogen gene (26) (Fig. $1 B$ ). The exon-intron boundary in both genes was identical. Of the 15 base pairs of coding sequence contained in MP-1, three differed from the corresponding sequence in the plasminogen gene. A total of 59 base pairs of intron sequence from this portion of the plasminogen gene has been published (26), and within this region there were seven mismatches relative to the sequence of MP-1. Overall, these two sequences shared $86 \%$ sequence identity. These results are consistent with the MP-1 subclone being derived from the apo(a) gene.

A restriction map of the kringle 4-encoding sequences of apo(a) was made using PCR-amplified fragments generated from genomic DNA employing primers LP-9 and LP-10, and LP-2 and LP-3 (Fig. $1 A$ ). Restriction analysis of the amplified DNA disclosed a single site for BglII, EcoRI, and BamHI, and multiple PstI restriction sites (Fig. $1 A$ ). Genomic DNA was digested with these enzymes and Southern blotting was performed using MP-1 as a probe (Fig. $1 C$ ). Only a 5.5-kb band was identified with $B g l \mathrm{II}, E c o R I$, and BamHI (Fig. $1 C$ ). This was the expected result based on the presence of a single restriction site for these enzymes in the tandemly repeated 5.5-kb sequence. Similarly, when genomic DNA was cut with PstI, a 1.5-kb band was identified which was the expected result based on the restriction map of the amplified products (Fig. $1 A$ ). The fact that only a single fragment was seen with these various restriction enzymes suggests that there is a high degree of sequence conservation in the introns as well as exons of the kringle 4-encoding repeats. These results also indicate that the MP1 probe is specific for the apo(a) gene and does not detect other genomic sequences under the blotting conditions employed here.

No KpnI restriction sites were identified in the amplified kringle 4-specific fragments and when $K p n I$ was used to restrict genomic DNA, only a very large restriction fragment (>23 kb) was identified (Fig. 1 C). This large genomic KpnI fragment must contain multiple tandem copies of the kringle 4-encoding sequences.

The KpnI restriction fragment was too large to be accurately sized by conventional gel electrophoresis. To circumvent this problem, pulsed-field gel electrophoresis was employed. By alternating the electric fields at two different angles during electrophoresis, large DNA molecules ( $>20 \mathrm{~kb}$ ) can be fractionated (43). Genomic blotting of DNA size-fractionated in this manner was performed and MP-1 was used as a probe to detect the apo(a) kringle 4-encoding sequences. 102 unrelated Caucasian American individuals were studied and a total of $19 \mathrm{KpnI}$ restriction fragments were identified and are shown in Fig. 2. No individual had more than two restriction fragments and only 6 of the 102 individuals studied had a single KpnI restriction fragment. To further demonstrate that we were detecting the apo(a) and not the plasminogen gene, we probed one of the genomic blots with a plasminogen-specific probe. The probe contained sequences from the kringle 3-encoding region (which is not in the apo(a) gene) and only a single invariant band of $51 \mathrm{~kb}$ was seen (data not shown).

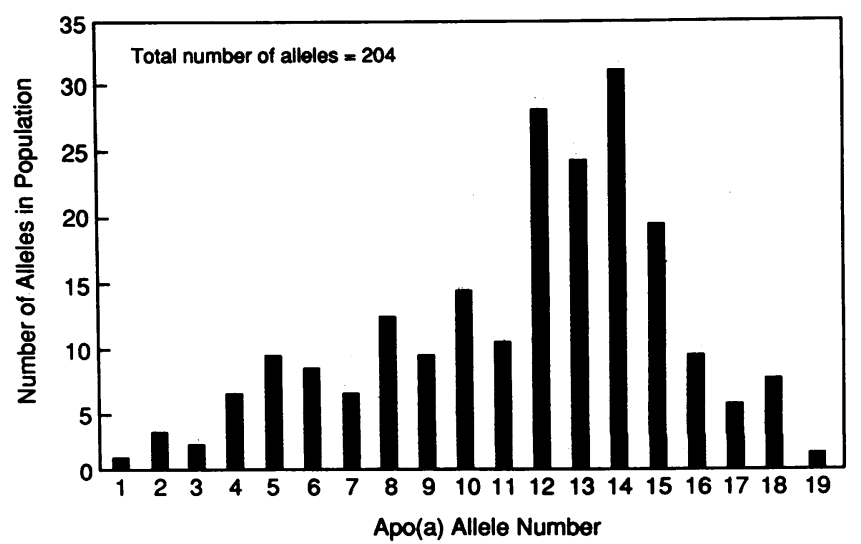

Figure 3. Frequency distribution of the 19 observed apo(a) alleles in 102 unrelated Caucasian American individuals. The numbers on the $x$-axis are arbitrary indices given to each of the 19 alleles (apo(a)1$a p o(a) 19)$ observed in this sample and are arranged from the smallest (left) to the largest (right) observed alleles. The relative frequencies of the alleles out of 204 total chromosomes are given on the $y$-axis. 
The restriction fragments were numbered consecutively according to their size from the smallest $(48 \mathrm{~kb}$ ) fragment to the largest $(190 \mathrm{~kb}) \mathrm{KpnI}$ restriction fragment. Each apo(a) allele was designated by a number i.e., from apo(a) 1 to apo(a) 19 . The migration of the lambda phage concatamer standards varied by up to $5 \%$ between gels preventing an allele classification based on size. Samples from individuals with a KpnI restriction fragment corresponding to each of the 19 sizes served as standards in the analysis of new subjects. Lymphocytes from the standard individuals were transformed using the Epstein-Barr virus (44) and genomic DNA plugs were made. For each new subject studied, the apo(a) allele classifications were determined by their relative migration on the same gel with one of the 19 preselected standards. For example, in Fig. 2, subject $\mathrm{C}$ was determined to have an apo(a) 3 allele based on comigration of his KpnI fragment with that of the apo(a) 3 standard (subject D).

When the KpnI fragments were analyzed according to size, a step-ladder effect was apparent (Fig. 2). The estimated size difference between adjacent fragments ranged from 4 to $28 \mathrm{~kb}$. In general, the lengths of the fragments increased in size by multiples of 5-6 kb. Based on the PCR-directed amplification studies of the kringle 4-encoding region and genomic blotting, each repeat was $5.5 \mathrm{~kb}$ in length. This result suggested that the variation in $K p n I$ fragment size was due to differing numbers of kringle 4-encoding sequences. Consistent with this interpretation is the fact that the longer $K p n I$ restriction fragments tended to have a more intense autoradiographic signal than did the shorter fragments (Fig. 2), as would be expected if they contained a greater number of kringle 4 repeats to hybridize with the probe. It would not be surprising to find additional apo(a) alleles in the population since some of the fragments are separated by $>5.5 \mathrm{~kb}$ and thus differ by more than a single kringle 4 repeat.
The frequency distribution of the 19 different apo(a) alleles identified in the 102 Caucasian American individuals studied is shown in Fig. 3. The most common allele was no. 14, which comprised $15.2 \%$ of the total apo(a) alleles in the sample. The distribution of alleles was skewed towards those of larger size fragments.

The distribution of plasma $\mathrm{Lp}(\mathrm{a})$ levels was similar to that which has been previously reported for other Caucasian individuals $(5,6)$ (data not shown). The levels of $\operatorname{Lp}(\mathrm{a})$ were highly skewed towards those of lower levels. Fig. 4 shows the relationship between the size of the apo(a) KpnI restriction fragments and the level of plasma $L p(a)$. The apo(a) KpnI restriction fragments are given on the $x$ - and $y$-axes making up the "floor" of the diagram. Allele no. 1 (on the $x$-axis) represents the smaller apo(a) allele in the heterozygotes. A bar was drawn at the intersection of the two allele designations to define the apo(a) genotype. The level of the plasma $\operatorname{Lp}(a)$ is shown on the $z$-axis. The height of the bar represents the mean of the levels of all individuals with that particular apo(a) genotype. In general, the smaller alleles tended to be dominant over large alleles in establishing $\operatorname{Lp}(\mathrm{a})$ levels. The smaller apo(a) alleles were generally associated with higher levels of plasma $L p(a)$, as reflected by the sizes of the bars decreasing from back to front. However, this relationship was not invariant and exceptions were apparent; for example, there is an individual with apo(a) genotype 14/17 who has a level of $\mathrm{Lp}(\mathrm{a})$ of $35 \mathrm{mg} / \mathrm{dl}$. Adding the numbers of the two alleles together for each individual creates an index for the number of kringle 4 repeats. The rank correlation coefficient between this index of the number of kringle 4 repeats and plasma $\mathrm{Lp}(\mathrm{a})$ levels was -0.41 .

The relationship between the size of the KpnI fragment and the protein was evaluated by performing immunoblot analysis of plasma using an apo(a)-specific antibody. The results of Southern blotting of $K p n I$ restricted genomic DNA (panel $A$ )

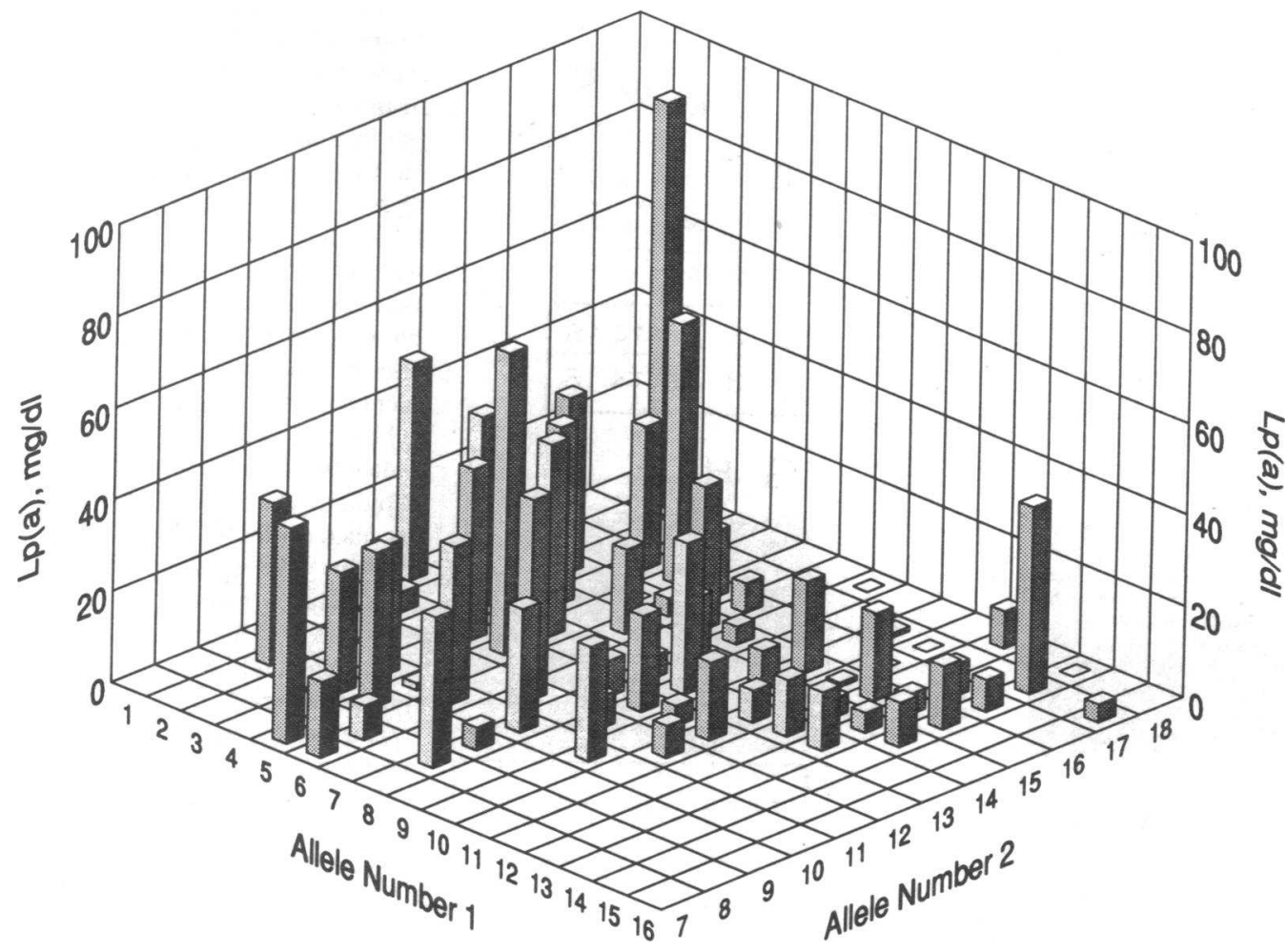

Figure 4. Three-dimensional graph showing the relationship between the apo(a) genotypes and average plasma Lp(a) levels. The $x$ - and $y$ axes in the "floor" of the graph identify the apo(a) alleles. Alleles within a diploid genotype were first ordered smallest to largest. The smaller of the two alleles is graphed on the left side of the floor; the larger of the two alleles on the right side. The heights of the bars rising out of the floor (the $z$-axis) indicate the magnitude of average $\mathrm{Lp}(\mathrm{a})$ levels (mg/dl) for that genotype. 
and immunoblotting of apo(a) (panel $B$ ) on six randomly selected individuals are shown in Fig. 5. The sizes of the apo(a) isoforms correlated well with the sizes of the KpnI restriction fragments. In heterozygotes, the amount of apo(a) protein associated with each isoform was often not the same. For example, individual $\mathrm{C}$ had a genotype $a p o(a) 4 / a p o(a) 16$ and the isoform with a lower molecular weight was much more abundant than the higher molecular weight isoform, as inferred by the relative signal intensities on the immunoblot (panel $B$ ). In general, the larger sized $K p n I$ fragments were associated with less plasma apo(a) protein.

Pulsed-field gel electrophoresis and genomic blotting of five individuals homozygous for a single $K p n I$ restriction fragment is shown in of Fig. 5 C. For each subject studied, the plasma apo(a) protein was analyzed by Western blotting and disclosed only a single apo(a) isoform (Fig. $5 \mathrm{D}$ ). Individual $\mathrm{G}$ is homozygous for apo(a)6 and yet has an $\mathrm{Lp}(\mathrm{a})$ level of only $7 \mathrm{mg} / \mathrm{dl}$. Though he was homozygous for one of the smaller alleles, he has a relatively low level of plasma $\mathrm{Lp}(\mathrm{a})$. Individual $\mathrm{J}$ who is homozygous for $a p o(a) 14$ has a level that is over twice his level despite having a much larger fragment. Pedigree analysis confirmed that he was a true homozygote for $a p o(a) 6$, and not heterozygous for a deleted apo(a) gene. Samples $B$ and $K$ in Fig. 5 are from the same individual who is homozygous for apo(a)16. She was of Asian descent and, thus, excluded from the statistical analysis of the apo(a) genotypes and plasma levels of $\mathrm{Lp}(\mathrm{a})$ shown in Fig. 4.

These findings are consistent with previous studies which found an inverse correlation between the number of kringle 4-encoding sequences and the level of plasma $\operatorname{Lp}(\mathrm{a})(16,30$, 31). To determine whether genetic determinants other than the number of kringle 4 repeats at the apo(a) locus contribute to the plasma level of $L p(a)$, segregation analysis of the apo(a) gene was performed in 12 families. First, we confirmed that the $K p n I$ restriction fragments were inherited in a manner consistent with a single polymorphic locus. Fig. 6 shows the analysis of a pedigree in which the four parental apo(a) alleles generated $K p n I$ restriction fragments of different sizes. The fragments segregated to the four offspring $(c-f)$ in a co-dominant Mendelian fashion. The father had a level of $\mathrm{Lp}(\mathrm{a})$ which was below the detection limits of the ELISA assay $(<1.0 \mathrm{mg} / \mathrm{dl})$. This does not mean he does not have any plasma $L p(a)$. If more plasma is used, he has detectable apo(a) protein on immunoblotting. The mother had a plasma Lp(a) level of $32 \mathrm{mg} / \mathrm{dl}$. The only child to inherit allele $a p o(a) 7$ from the mother was the first child and he had an $\mathrm{Lp}$ (a) level of $28 \mathrm{mg} / \mathrm{dl}$. The other three children had little or no detectable $\mathrm{Lp}(\mathrm{a})$, and they all inherited apo(a) 15 from the mother. These results suggest that the mother's $a p o(a) 15$ allele, and both apo(a) alleles of the father, were associated with little or no plasma level of apo(a). The mother's $a p o(a) 7$ allele was the only apo(a) allele in this family that was associated with an appreciable level of $\mathrm{Lp}(\mathrm{a})$. The single offspring who inherited this allele had an Lp(a) level that was the sum, rather than the mean, of the expected contributions of each parental allele.

The relationship between the apo(a) genotype and the size of the apo(a) protein was also examined by analyzing a family (Fig. 7). The parents, individuals $a$ and $b$, had genotypes apo(a)5/apo(a) 16 and apo(a)4/apo(a)9, respectively (Fig. $7 \mathrm{~A}$ ). The relative sizes of their apo(a) isoforms correlated with the size of the KpnI restriction fragment (Fig. 7 B). The apo(a) isoforms, as well as the KpnI fragments, segregated in a Mendelian fashion. Two of the children, $c$ and $f$, inherited the same apo(a) genes from each parent, apo(a) 16 from the father and

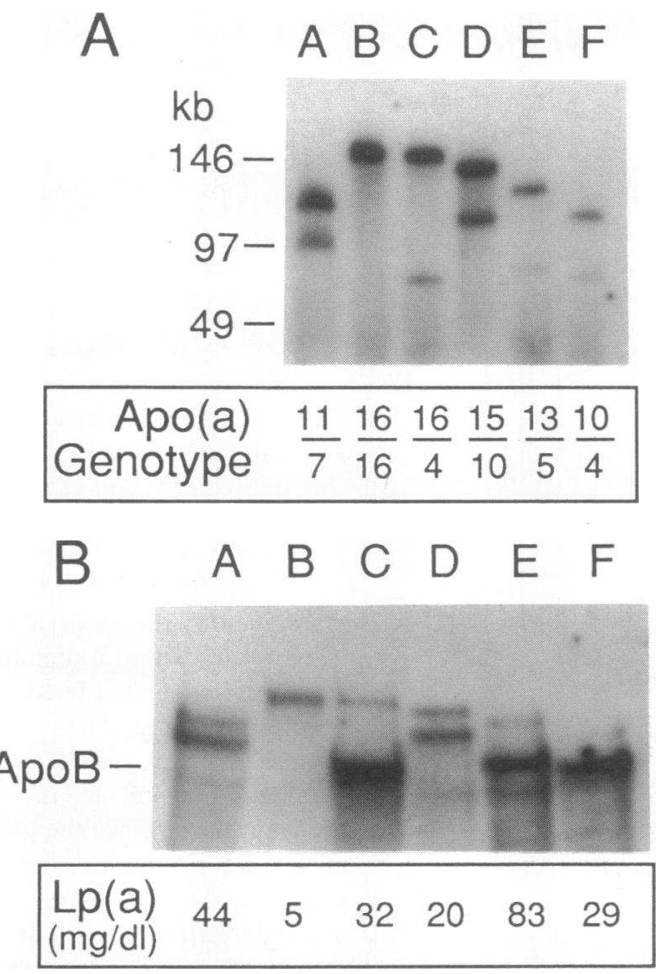

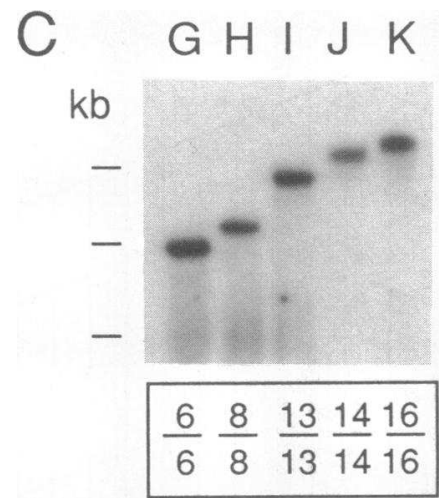

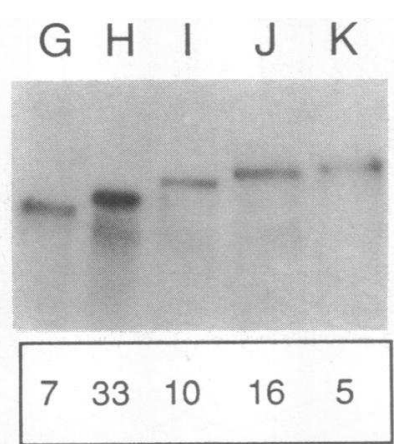

Figure 5. Southern blot analysis of apo(a) gene and Western blot analysis of the apo(a) protein in six unselected individuals $(A$ and $B)$ and in five individuals homozygous for the KpnI restriction fragment $(C$ and $D$ ). Pulsed-field gel electrophoresis and genomic blotting was performed using high molecular weight leukocyte DNA which had been digested with KpnI, as described in Fig. 2. Between 0.5 and $10 \mu$ l of whole blood $[0.25 \mu \mathrm{g}$ of $\mathrm{Lp}(\mathrm{a})]$ was size-fractionated on a 3-7\% gradient polyacrylamide reducing gel in the presence of SDS. Delipidated LDL was used as size standard. The apparent molecular mass of ApoB is $513 \mathrm{kD}$. The proteins were transferred to a nitrocellulose membrane and then the membrane was stained with Ponceau-S to determine the position of apo B-100. The filter was incubated with IgGIA ${ }^{2}$, a mouse anti-human apo(a) MAb, before incubation with an ${ }^{125} \mathrm{I}-$ labeled polyclonal rabbit antimouse antibody, as described in

Methods. The filters were washed and exposed to XAR- 5 film for $18 \mathrm{~h}$ with an intensifying screen. The plasma Lp(a) levels given are the mean of 3 separate determinations by ELISA, as described in Methods. 


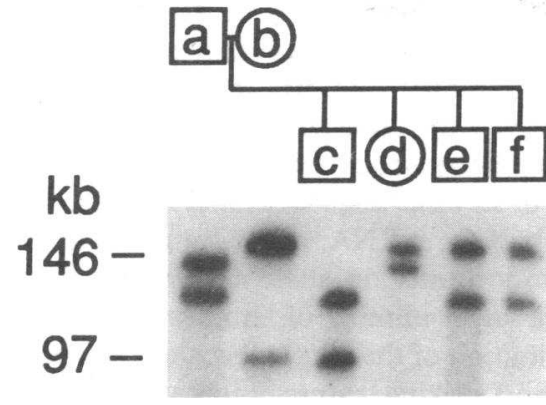

\begin{tabular}{|r|lllll|}
\hline $\begin{array}{r}\text { Apo(a) } \\
\text { Genotype }\end{array}$ & $\frac{14}{12} \frac{15}{7} \frac{12}{7} \frac{15}{14} \frac{15}{12} \frac{15}{12}$ \\
\hline \hline $\begin{array}{r}\text { Lp(a) } \\
(\mathrm{mg} / \mathrm{dll})\end{array}$ & $<13228<1 \quad 1 \quad 1$ \\
\hline
\end{tabular}

Figure 6. Southern blot analysis of the apo(a) gene in a Caucasian American pedigree. Genomic DNA was size-fractionated by pulsedfield gel electrophoresis, transferred to a nylon membrane, probed with MP-1, washed, and exposed to film for $18 \mathrm{~h}$, as described in the legend to Fig. 2 and Methods. The circles and squares denote women and men, respectively. In both pedigrees, the first two lanes of the autoradiogram show results of the analysis of the parents, and the subsequent five lanes demonstrate the Mendelian inheritance of the $K p n I$ restriction fragments to the offspring. Below the blots are the apo(a) genotypes as determined by the size of the KpnI restriction fragments relative to the migration of the standards shown in Fig. 2. The plasma Lp(a) levels are the mean of two separate determinations on different plasma samples by the ELISA assay, as described in Methods.

apo(a)9 from the mother, and they both had the same sized apo(a) isoforms. They also had nearly identical levels of plasma $\mathrm{Lp}(\mathrm{a})(9 \mathrm{vs} .7 \mathrm{mg} / \mathrm{dl})$. The remainder of the offspring had different apo(a) genotypes and very different levels of plasma $L p(a)$. The $a p o(a) 5$ allele of the father was invariably associated with a higher level of $\mathrm{Lp}(\mathrm{a})$ than the $a p o(a) 4$ allele from the mother. Individual $g$ had a markedly elevated plasma level of $\operatorname{Lp}(a)(75$ $\mathrm{mg} / \mathrm{dl}$ ), which was slightly less than the sum of both parents' levels. In the families we studied, the Lp(a) level of an offspring was the sum, rather than the mean, of the level associated with each parental allele.

Among the 12 families we studied, there were 10 sibling pairs with an identical apo(a) genotype and nine of these had plasma Lp(a) levels within $2 \mathrm{mg} \%$ of each other (Table I). At least four of the sib pairs (1-4 in Table I) had levels that were clearly different from the other siblings in the family. The high concordance of $\mathrm{Lp}(\mathrm{a})$ levels among siblings with the same apo(a) genotype suggest that factors at the apo(a) locus other than number of kringle 4 repeats are contributing to the plasma Lp(a) level.

\section{Discussion}

In this study, we used pulsed-field gel electrophoresis to identify a large $K p n I$ restriction fragment from the apo(a) gene that contains most, if not all, of the sequences encoding the kringle 4 repeats. The studies were made possible by the identification of a probe that hybridizes specifically to the kringle 4-encoding region of the apo(a) gene, and not to the plasminogen gene, or to any of the numerous apo(a) or plasminogen pseudogenes
$(27,28)$. Using pulsed-field gel electrophoresis we genotyped 102 unrelated Caucasian Americans and we found 19 fragments that, in general, differed in size by multiples of $\sim 5 \mathrm{~kb}$. The size of a single apo(a) kringle 4-encoding sequence was estimated to be $5.5 \mathrm{~kb}$ suggesting that the length polymorphism of the KpnI fragment is due to variations in number of sequences encoding kringle 4 . Our studies suggest that most (if not all) of the size differences in the apo(a) protein are due to varying numbers of kringle 4-encoding repeats in the apo(a) gene, as was originally proposed by McLean et al. (18). In support of this hypothesis, the size of the KpnI restriction fragment always correlaied with the size of the apo(a) protein, as determined by SDS-PAGE.

Although the pulsed-field gels revealed the relative number of kringle 4 repeats in each allele, we are as yet unable to detect the precise number in each gene. This is because we do not know the precise location of the KpnI sites that flank the kringle 4-encoding segment, and hence we do not know how much flanking DNA is included in this segment. In an attempt to identify the location of the $5^{\prime} K p n I$ restriction site, we used a radiolabeled fragment from the signal sequence-encoding region of the apo(a) cDNA (18) to probe a KpnI-restricted genomic blot. Several nonpolymorphic bands, all smaller than 48 $\mathrm{kb}$, were seen (data not shown). Since the probe shared $100 \%$ sequence identity with the plasminogen gene, it presumably hybridized to that gene as well as to apo(a) and plasminogen pseudogenes $(27,28)$. The large polymorphic $K p n I$ fragments seen with the apo(a) Kringle 4-specific probe were not visualized. We conclude that the $5^{\prime} K p n I$ site was in the intron between the signal sequence-encoding exon(s) and the first kringle 4 repeat. Downstream of the kringle 4 repeated sequences there is at least one $K p n I$ site in an intron associated with the kringle 5-encoding sequences. This site was identified by performing PCR using two oligonucleotides: one from the $3^{\prime}$ end of the kringle 5 and the other from the $5^{\prime}$ end of the protease
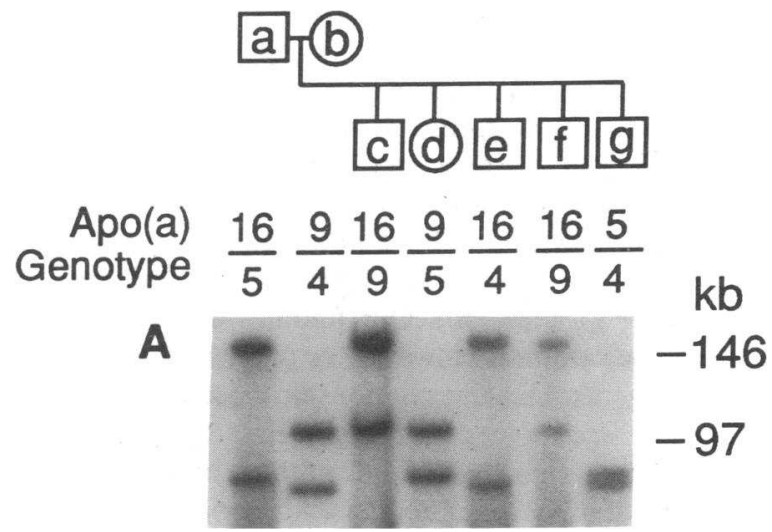

$\mathbf{B}$

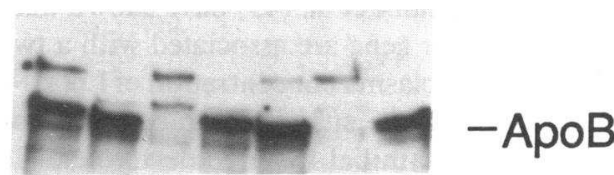

\section{Lp(a) (mg/dl) 542795022775}

Figure 7. (A) Southern blot analysis of the apo(a) gene and $(B)$ immunoblot analysis of the apo(a) protein in a pedigree. Pulsed-field gel electrophoresis and immunoblot analysis of the apo(a) gene and protein were performed as described in the legend to Fig. 5. 
Table I. Apo(a) Genotypes and Lp(a) Levels in Sib Pairs

\begin{tabular}{|c|c|c|c|c|}
\hline \multicolumn{3}{|c|}{ Sibs with identical genotype } & \multicolumn{2}{|c|}{ Other sibs } \\
\hline \multirow[t]{2}{*}{$\begin{array}{c}\text { Apo(a) } \\
\text { genotype* }\end{array}$} & \multicolumn{2}{|c|}{$\begin{array}{l}\text { Plasma } \\
\text { Lp }(a)^{*}\end{array}$} & $\underset{\text { genotypes* }}{\text { Apo(a) }}$ & $\begin{array}{l}\text { Plasma } \\
\text { Lp }(a)^{*}\end{array}$ \\
\hline & \multicolumn{2}{|c|}{$m g / d l$} & & $m g / d l$ \\
\hline $4 / 10$ & $41^{8}$ & 42 & $10 / 14 ; 6 / 14$ & $<1 ; 16$ \\
\hline $9 / 16$ & 7 & 9 & $5 / 9 ; 4 / 5$ & $50 ; 75$ \\
\hline $12 / 14$ & $6^{8}$ & $9^{8}$ & $8 / 12$ & $<1^{8}$ \\
\hline $12 / 15$ & 1 & 1 & $14 / 15 ; 7 / 12$ & $<1 ; 28$ \\
\hline $14 / 17$ & 1 & 13 & $14 / 15 ; 15 / 17$ & $2 ; 3$ \\
\hline $14 / 15$ & $<1^{8}$ & $<1^{8}$ & $15 / 18$ & $<1^{8}$ \\
\hline $6 / 16$ & 5 & 6 & $6 / 6 ; 6 / 6 ; 15 / 15$ & $7 ; 7 ; 6$ \\
\hline $6 / 6$ & 7 & 7 & $6 / 16 ; 6 / 16 ; 15 / 16$ & $5 ; 6 ; 6$ \\
\hline $2 / 18$ & $<1^{8}$ & $<1^{8}$ & $15 / 18$ & $<1^{8}$ \\
\hline $11 / 15$ & $<1^{8}$ & $<1^{8}$ & $15 / 17 ; 8 / 11$ & $<1^{8} ; 7^{8}$ \\
\hline
\end{tabular}

* Apo(a) genotypes determined as described in Methods and Fig. 2. * Plasma Lp(a) levels were determined using the ELISA assay, as described in Methods. The value given is the mean of at least two samples, unless indicated.

${ }^{8} \mathrm{Lp}$ (a) level determined by ELISA on a single fasting plasma sample.

domain of the apo(a) gene. Two bands of $\sim 2.8 \mathrm{~kb}$ were identified and both contained a KpnI site. One fragment was confirmed to be from the apo(a) gene by subcloning and sequencing (data not shown). This site may be the $3^{\prime}$ boundary of the $K p n I$ restriction fragment.

If our KpnI restriction map is correct, it suggests that the number of kringle 4-encoding repeats in the apo(a) gene ranges from $\sim 9$ to $\sim 35$. The most frequent apo(a) allele in our sample was $a p o(a) 14$ which, based on its size (146 kb), would be expected to contain $\sim 27$ repeats. The apo(a) cDNA that was originally cloned by McLean et al. (18) was reestimated to contain $~ 32$ kringle 4-encoding sequences (28) which would correspond to an allele with a size between $a p o(a) 18$ and apo(a)19. The actual number of kringle 4-encoding repeats contained in each fragment can only be determined when the gene is more fully characterized.

After the original suggestion of Utermann and co-workers (12), several investigators have noted an inverse relationship between the size of the apo(a) protein and the amount of plasma $\operatorname{Lp}(\mathrm{a})(13,16,30)$. Our findings are consistent with these previous studies. However, as previously noted, exceptions to the general inverse relationship exist. In different families the same size apo(a) gene can give rise to proteins that have very different plasma levels. Some of this variation may be due to the effect of other gene products. At least one other gene has been shown to impact importantly on the level of plasma Lp(a). Utermann et al. (45) have shown that mutations in the LDL receptor gene are associated with a two- to threefold increase in the plasma concentration of $\operatorname{Lp}(a)(45)$. In our population, none of the subjects studied had clinical or laboratory evidence of familial hypercholesterolemia. Thus, additional factors, some of which are genetic, must modify the level of plasma $L p(a)$.

The current data suggest that in addition to the number of kringle 4 repeats, the level of apo(a) in plasma is controlled by other factors linked to the apo(a) gene. This follows from the observation that the plasma level of $\operatorname{Lp}(a)$ among sib pairs with an identical apo(a) genotype were strongly correlated, whereas the levels among unrelated individuals with the same-sized apo(a) gene frequently were not. This suggests that all the apo(a) alleles of the same size do not have identical sequences. There could be sequence differences in the promotor region of the gene, or in other sequences that alter the transcription or translation of the mRNA, or the transport of the protein that impact importantly on allele expression. We are currently studying a larger number of families to accurately determine the contribution of the apo(a) locus to the level of $\operatorname{Lp}(\mathrm{a})$.

The most striking feature of this analysis of the apo(a) gene is the unprecedented degree of length polymorphism involving coding sequences of a gene. The apo(a) gene probably arose from the plasminogen gene by exon shuffling and subsequent expansion and contraction of the kringle 4-encoding sequence by homologous recombination and unequal exchange (18). The sequence homology that has been maintained between the tandem kringle 4-encoding repeats (in both the noncoding and coding regions) suggests that gene conversion is also operative at this locus. Why the apo(a) gene is so polymorphic in size is unclear and may not be understood until more is known about the function of this enigmatic lipoprotein. We identified 17 tandem copies of the dinucleotide $d(C A)_{n}$ in an intervening sequence of the kringle 4 repeat (data not shown). This class of repetitive sequences has been implicated in promoting recombination and gene conversion in the eukaryotic genome (46-49), and may play a role in the generation of length polymorphism at the apo(a) locus.

Previous studies examined the segregation of the apo(a) protein and gene in pedigrees also suggested that the apo(a) gene itself is an important determinant of the plasma level of Lp(a) (22, 50-53). A problem which has been encountered when the apo(a) protein have been used for segregation analysis, is that the isoforms are not in Hardy-Weinberg equilibrium (12-16). Initially, this was attributed to a frequent null allele in the population $(12,14)$. More recently, however, Gaubatz et al. (13) were able to detect plasma apo(a) by immunoblotting in over $99 \%$ of individuals studied and identified 11 different isoforms. $60 \%$ of their subjects had only a single apo(a) isoform (13) detectable by immunoblotting and the isoforms were not in Hardy-Weinberg equilibrium. In contrast, only $6 \%$ of our samples were homozygous for the same sized apo(a) gene and this is the exact number expected if the alleles were in HardyWeinberg equilibrium. The probable explanation for this discrepancy is that the methods currently used to analyze the apo(a) protein do not detect all of the apo(a) gene products. Knowledge of the apo(a) gene structure has enabled us to optimize conditions for analyzing the protein isoforms by immunoblotting, and we have found no evidence of frequent null alleles at the apo(a) locus.

\section{Acknowledgments}

We wish to acknowledge Dr. Gerd Utermann for very helpful discussions at the initiation of these studies. We wish to thank Drs. Michael Brown, Joseph Goldstein, and David Russell for their helpful comments, and Dr. Sue Richards for her generous assistance with the pulsed-field gel electrophoresis. Tommy Hyatt, Evan Tobin, and Kathy Schueler provided excellent technical assistance.

This work was supported by the grants from the Perot Family Foundation and grants HL-20948, HL-40613, and 90-IJ-CX-0038 from the National Institutes of Health. H. H. Hobbs is a Syntex Scholar and an Established Investigator of the American Heart Association. C. Lackner is the recipient of a Schroedinger Scholarship. 


\section{References}

1. Berg, K., G. Dahlen, and M. H. Frinc. 1974. Lp(a) lipoprotein and prebeta 1 -lipoprotein in patients with coronary heart disease. Clin. Genet. 6:230-235.

2. Kostner, G. M., P. Avogaro, G. Cazzolato, E. Marth, G. Bittolo-Bon, and G. B. Qunici. 1981. Lipoprotein Lp(a) and the risk for myocardial infarction. Atherosclerosis. 38:51-61.

3. Rhoads, G. G., G. Dahlen, K. Berg, N. E. Morton, and A. L. Dannenberg. 1986. Lp(a) lipoprotein as a risk factor for myocardial infarction. JAMA (J. Am. Med. Assoc.). 256:2540-2544.

4. Dahlen, G. H., J. R. Guyton, M. Attar, J. A. Farmer, J. A. Kautz, and A. M. Gotto. 1986. Association of levels of lipoprotein Lp(a), plasma lipids, and other lipoproteins with coronary artery disease documented by angiography. Circulation. 74:758-765.

5. Scanu, A. M., and G. M. Fless. 1990. Lipoprotein(a). Heterogeneity and biological relevance. J. Clin. Invest. 85:1709-1715.

6. Utermann, G. 1989. The mysteries of lipoprotein (a). Science (Wash. DC). 246:904-910

7. Utermann, G., and W. Weber. 1983. Protein composition of Lp(a) lipoprotein from human plasma. FEBS (Fed. Eur. Biochem. Soc.) Lett. 154:357-361.

8. Gaubatz, J. W., C. Heideman, A. M. Gotto, Jr., J. D. Morrisett, and G. H. Dahlen. 1983. Human plasma lipoprotein(a): Structural properties. J. Biol. Chem. 258:4582-4589.

9. Fless, G. M. M. E. ZumMallen, and A. M. Scanu. 1985. Isolation of apolipoprotein(a) from lipoprotein(a). J. Lipid Res. 26:1224-1229.

10. Gaubatz, J. W., M. V. Chari, M. L. Nava, J. R. Guyton, and J. D. Morrisett 1987. Isolation and characterization of the two major apoproteins in huma lipoprotein (a). J. Lipid Res. 28:69-79.

11. Fless, G. M., C. A. Rolih, and A. M. Scanu. 1984. Heterogeneity of human plasma lipoprotein(a): isolation and characterization of the lipoprotein subspecies and their apoproteins. J. Biol. Chem. 259:11470-11478.

12. Utermann, G., H. J. Menzel, H. G. Kraft, H. C. Duba, H. G. Kemmler, and C. Seitz. 1987. Lp(a) glycoprotein phenotypes-inheritance and relation to Lp(a)-lipoprotein concentration in plasma. J. Clin. Invest. 80:458-465.

13. Gaubatz, J. W., K. I. Ghanem, J. Guevara, Jr., M. L. Nava, W. Patsch, and J. D. Morrisett. 1990. Polymorphic forms of human apolipoprotein[a]: inheritance and relationship of their molecular weights to plasma levels of lipoprotein[a]. J. Lipid Res. 31:603-613.

14. Utermann, G., C. Duba, and H. J. Menzel. 1988. Genetics of the quantitative Lp(a) lipoprotein trait. II. Inheritance of Lp(a) glycoprotein phenotypes. Hum. Genet. 78:47-50.

15. Utermann, G., H. G. Kraft, H. J. Menzel, T. Hopferwieser, and C. Seitz 1988. Genetics of the quantitative Lp(a) lipoprotein trait. Hum Genet 78:41-46.

16. Boerwinkle, E., H. J. Menzel, H. G. Kraft, and G. Uterman. 1989. Contribution of Lp(a) glycoprotein phenotype to normal lipid variation. Hum. Genet. 8:73-78.

17. Eaton, D. L. G. M. Fless, W. J. Kohr, J. W. McLean, Q-T. Xu, C. G. Miller, R. M. Lawn, and A. M. Scanu. 1987. Partial amino acid sequence of apolipoprotein(a) shows that it is homologous to plasminogen. Proc. Natl. Acad. Sci. USA. 84:3224-3228.

18. McLean, J. W., J. E. Tomlinson, W. J. Kuang, D. L. Eaton, E. Y. Chen, G. M. Fless, A. M. Scanu, and R. M. Lawn. 1987. cDNA sequence of human apolipoprotein(a) is homologous to plasminogen. Nature (Lond.). 330:132-137.

19. Malinowski, D. P., J. E. Sadler, and E. W. Davie. 1984. Characterization of a complementary deoxyribonucleic acid coding for human and bovine plasminogen. Biochemistry. 23:4243-4250.

20. Forsgren, M. B. Raden, M. Israelsson, K. Larsson, and L-O. Heden. 1987. Molecular cloning and characterization of a full-length cDNA clone for human plasminogen. FEBS (Fed. Eur. Biochem. Soc.) Lett. 213:254-260.

21. Murray, J. C. K. H. Buetow, M. Donovan, S. Hornung A. G. Motulsky, C. Disteche, K. Dyer, K. Swisshelm, J. Anderson, E. Giblett, et al. 1987. Linkage disequilibrium of plasminogen polymorphisms and assignment of the gene to human chromosome 6q26-6q27. Am. J. Hum. Genet. 40:338-350.

22. Drayna, D. T. R. A. Hegele, P. E. Hass, M. Emi, L. L. Wu, D. L. Eaton, R. M. Lawn, R. R. Williams, R. L. White, and J.-M. Lalouel. 1988. Genetic linkage between lipoprotein(a) phenotype and a DNA polymorphism in the plasminogen gene Genomics. 3.230-236.

23. Weitkamp, L. R., S. A. Guttormsen, and J. S. Schultz. 1988. Linkage between the loci for the Lp(a) lipoprotein (LP) and plasminogen (PLG). Hum. Genet. 79:80-82.

24. Lindahl, G., W. Gersdorf, H. J. Menzel, C. Duba, H. Cleve, S. Humphries, and G. Utermann. 1989. The gene for the Lp(a)-specific glycoprotein is closely linked to the gene for plasminogen on chromosome 6. Hum. Genet. 81:149-152.

25. Frank, S. L. I. Klisak, R. S. Sparkes, T. Mohandas, J. E. Tomlinson, J. W. McLean, R. M. Lawn, and A. J. Lusis. 1988. The apolipoprotein(a) gene resides on human chromosome $6 \mathrm{q} 26-27$, in close proximity to the homologous gene for plasminogen. Hum. Genet. 79:352-356.

26. Petersen, T. E M. R. Martzen, A Ichinose, and E W Davie 1990 Characterization of the gene for human plasminogen, a key proenzyme in the fibrinolytic system. J. Biol. Chem. 265:6104-6111.
27. Frank, S. L., I. Klisak, R. S. Sparkes, and A. J. Lusis. 1989. Short Communication: A gene homologous to plasminogen located on human chromosome 2q11-p11. Genomics. 4:449-451.

28. Koschinsky, M., U. Beisiegel, D. Henne-Bruns, D. L. Eaton, and R. M Lawn. 1990. Apolipoprotein(a) size heterogeneity is related to variable number of repeat sequences in its mRNA. Biochemistry. 29:640-644.

29. Hixson, J. E., M. L. Britten, G. S. Manis, and D. L. Rainwater. 1989 Apolipoprotein(a) (Apo(a)) glycoprotein isoforms result from size differences in apo(a) mRNA in baboons. J. Biol. Chem. 264:6013-6016.

30. Gavish, D., N. Azrolan, and J. L. Breslow. 1989. Plasma Lp(a) concentration is inversely correlated with the ration of kringle IV/kringle $\mathrm{V}$ encoding domains in the apo(a) gene. J. Clin. Invest. 84:2021-2027.

31. Lindahl, G., E. Gersdorf, H. J. Menzel, M. Seed, S. Humphries, and G. Utermann. 1990. Variation in the size of human apolipoprotein(a) is due to a hypervariable region in the gene. Hum. Genet. 84:563-567.

32. Menzel, H. J., H. Dieplinger, C. Lackner, F. Hoppichler, J. K. Lloyd, D. R. Muller, C. Labeur, P. J. Talmud, and G. Utermann. 1990. Abetalipoproteinemia with an apoB-100-lipoprotein(a) glycoprotein complex in plasma. $J$. Biol. Chem. 265:981-986.

33. Beisiegel, U., W. J. Schneider, J. L. Goldstein, R. G. W. Anderson, and M. S. Brown. 1981. Monocolonal antibodies to the low density lipoprotein receptor as probes for study of receptor-mediated endocytosis and the genetics of familial hypercholesterolemia. J. Biol. Chem. 256:11923-11931.

34. Lipid Research Clinic Program. 1982. Lipid and Lipoprotein Analysis: Manual of Laboratory Operations. Department of Health, Education and Welfare Publ. NIH/75-628. Government Printing Office, Washington, DC.

35. Nakane, P. K., and A. Kawaoi. 1974. Peroxidase labeled antibody. A new method of conjugation. J Histochem Cytochem. 22:1084-1091.

36. Saiki, R. K., S. Scharf, F. Faloona, K. B. Mullis, G. T. Horn, H. A. Erlich, and N. Arneheim. 1985. Enzymatic amplification of $\beta$-globin genomic sequences and restriction site analysis for diagnosis of sickle cell anemia. Science (Wash DC). 230:1350-1354

37. Mathews, M. K., C. L. Smith, and C. R. Cantor. 1988. High-resolution separation and accurate size determination in pulsed-field gel electrophoresis of DNA. 1. DNA size standards and the effect of agarose and temperature. Biochemistry. 27:9204-9210.

38. Hobbs, H. H., M. S. Brown, J. L. Goldstein, and D. W. Russell. 1986. Deletion of exon encoding cysteine-rich repeat of LDL receptor alters its binding specificity in a subject with familial hypercholesterolemia. J. Biol. Chem. 261:13114-13120.

39. Church, G. M., and W. Gilbert. 1984. Genomic sequencing. Proc. Natl. Acad. Sci. USA. 81:1991-1995.

40. Vogel, F., and A. G. Motulsky. 1986. Human Genetics. 2nd edition. Springer-Verlag, New York. 642-644.

41. Dixon, W. J. 1988. BMDP Statistical Software Manuals. University of California Press, Berkeley, CA.

42. Conover, W. J. 1980. Practical Nonparametric Statistics. 2nd edition. John Wiley \& Sons, New York.

43. Lai, E., B. W. Birren, S. M. Clark, M. I. Simon, and L. Hood. 1989. Pulsed field gel electrophoresis. BioTechniques. 7:35-42.

44. Miller, G., and M. Lipman. 1973. Release of infectious Epstein Barr virus by transformed marmoset leukocytes. Proc. Natl. Acad. Sci. USA. 70:190-194.

45. Utermann, G., F. Hoppichler, H. Dieplinger, M. Seed, G. Thompson, and E. Boerwinkle. 1989. Defects in the low density lipoprotein receptor gene affect lipoprotein (a) levels: multiplicative interaction of two gene loci associated with premature atherosclerosis. Proc. Natl. Acad. Sci. USA. 86:4171-4174.

46. Slightom, J. L., A. E. Blechl, and O. Smithies. 1980. Human fetal ${ }^{6} \gamma$ - and $\gamma$-globin genes: complete nucleotide sequences suggest that DNA can be exchanged between these duplicated genes. Cell. 21:627-638.

47. Shen, S., J. L. Slightom, and O. Smithies. 1981. A history of the human fetal globin gene duplication. Cell. 26:191-203.

48. Treco, D., and N. Arnheim. 1986. The evolutionarily conserved repetitive sequence $\mathrm{d}(\mathrm{TG} \cdot \mathrm{AC})_{\mathrm{n}}$ promotes reciprocal exchange and generates unusual recombinant tetrads during yeast meiosis. Mol. Cell. Biol. 6:3934-3947.

49. Boehm, T., L. Mengle-Gaw, U. R. Kees, N. Spurr, I. Lavenir, A. Forster, and T. H. Rabbitts. 1989. Alternating purine-pyrimidine tracts may promote chromosomal translocations seen in a variety of human lymphoid tumours. EMBO (Eur. Mol. Biol. Organ.) J. 8:2621-2631.

50. Sing, C. F., J. S. Schultz, and D. C. Shreffler. 1974. The genetics of the Lp Antigen. II. A family study and proposed models of genetic control. Ann. Hum. Genet. 38:47-56.

51. Iselius, L., G. Dahlén, U. deFaire, and T. Lundman. 1981. Complex segregation analysis of the Lp(a)/pre- $\beta_{1}$-lipoprotein trait. Clin. Genet. 20:147151.

52. Hasstedt, S. J., D. E. Wilson, C. Q. Edwards, W. N. Cannon, D. Carmelli, and R.R. Williams. 1983. The genetics of quantitative plasma Lp(a): analysis of a large pedigree. Am. J. Med. Genet. 16:179-188.

53. Berg, K. I. Kondo, D. Drayna, and R. Lawn. 1990. Restriction site polymorphism at the LPA (Lp(a) apolipoprotein; apolipoprotein(a)) locus. Clin. Genet. 37:473-480. 